Aliran Eksistensialisme dalam Pandangan Filsafat Pendidikan Islam

Rabiatul Adawiah

Madrasah dan Transformasi Intelektual Muhdi

Kisah Keluarga Teladan dalam Al-Qur'an (Inspirasi Membangun Negara yang Thayyibah) Rahmat Sholihin

Tasawuf dalam Pandangan Nurcholish Madjid Ilham Masykuri Hamdie dalam Buku The Tao of Islam) Erni Susilawati

Islam, Keindonesiaan, dan Kemanusiaan

(Telaah Pemikiran Ahmad Syafii Maarif) Damanhuri

Pandangan Kritis Islam Liberal atas Isu-Isu Kontemporer Muhammad Taufik 


\section{AL - BANJARI \\ Jurnal Ilmiah Ilmu-Ilmu Keislaman}

Vol. 14, No. 1, Januari-Juni 2015

\section{DAFTAR ISI}

Aliran Eksistensialisme dalam Pandangan Filsafat Pendidikan Islam

Rabiatul Adawiah

Madrasah dan Transformasi Intelektual

Muhdi

Kisah Keluarga Teladan dalam Al-Qur'an (Inspirasi Membangun

Negara yang Thoyyibah)

Rahmat Sholihin

Tasawuf dalam Pandangan Nurcholish Madjid

Ilham Masykuri Hamdie

Psikologi Sufistik (Studi atas Pemikiran Sachiko Murata dalam Buku

The Tao of Islam)

60-75

Erni Susilawati

Islam, Keindonesiaan, dan Kemanusiaan (Telaah Pemikiran

Ahmad Syafii Maarif)

$76-84$

Damanhuri

Pandangan Kritis Islam Liberal atas Isu-Isu Kontemporer

85-105

Muhammad Taufik 


\title{
MADRASAH DAN TRANSFORMASI INTELEKTUAL
}

\author{
Muhdi \\ Fakultas Tarbiyah dan Keguruan, IAIN AntasariBanjarmasin. \\ E-mail: muhdi poliban@yahoo.com
}

\begin{abstract}
This paper attempts to map the characteristics of the development of the classical era of Islamic schools (madrasah). The study concludes that these developments have significant relevance for the future direction of the Islamic intellectual transformation until today. The Character of school development in classical era which gave full attention to the transfer of conventional religious sciences gave its own color for the implementation of religious life as well. Islamic Jurisprudence (Fiqh) which provided practical concepts in religious life became a definite curriculum content. This is a remarkable achievement. However, lately, the trend is considered to make the development of Islamic intellectual transformation become "unhealthy". This unhealthiness is the stressing point of this paper.
\end{abstract}

Keywords: Madrasah, Curriculum, Islamic Intellectual Transformation, and Religious sciences.

\section{Pendahuluan}

Perkembangan lembaga pendidikan Islam sebagai wahana transpormasi intelektual mengalami sejarahnya yang panjang. Pada masa awal perkembangannya, katakanlah dimulai sejak zaman Rasulullah Saw, pendidikan formal yang tersistematisasi dengan baik belumlah terselenggara. Apa yang dapat diklaim sebagai aktivitas pendidikan tidak lain dan oleh karena itu sulit dipisahkan dari upaya-upaya yang berkaitan dengan dakwah Islamiyah, yakni penyebaran atau penanaman dasar-dasar kepercayaan dan ibadah.

Berkenaan dengan hal di atas, pendidikan Islam yang semi formal --untuk tidak menyebut formal sepenuhnya--pada perkembangan selanjutnya di masa awal ini barangkali adalah proses pendidikan yang terjadi di rumah, dikenal dengan DaralArqam. $^{1}$

\footnotetext{
${ }^{1}$ Dar al-Arqam merujuk pada rumah al-Arqam Ibnu AbilArqam, sebagai tempat Rasulullah Saw mengajarkan pada para pengikutnya pokok-pokok ajaran Islam, serta membacakan ayat-ayat Al-Qur'an. Dan di sinilah sering dilakukan peng-Islam-an orang-orang yang secara sukarela mengucapkan dua kalimat syahadat.Lihat Ahmad Syalabi,Sejarab Pendidikan Islam, terj. Mucbtarjabja dan SanusiLatief, cet, I, Jakarta: Bulan Bintang, 1973, h.58.
} 
Pada perkembangan selanjutnya, ketika masyarakat Islam telah semakin kuat, pendidikan Islam seterusnya dilaksanakan pula di mesjid dalam bentuk halaqab; lingkaran belajar. Proses belajar di mesjid dalam bentuk halaqah ini tetap dipertahankan di masa khulafaurrasyidin, kekhalifahan Bani Ummayyah dan kekhalifahan Bani Abbasiyah. Pada masa terakhir ini,seiring dengan semakin besarnya minat atau jumlah kaum muslimin yang berkeinginan menuntut ilmu, mesjid kemudian diperlengkapi dengan Khan (funduq; penginapan) yang berfungsi sebagai asrama yang dibangun di samping mesjid, diperuntukkan terutama bagi pendatang dari jauh. Dari sinilah muncul istilah Mesjid Khan yang pada tahap perkembangan selanjutnya menjadi model bagi kemunculan madrasah. ${ }^{2}$

Ahmad Syalabi menjelaskan motivasi teknis perpindahan proses pendidikan Islam dari mesjid ke madrasah. Dikemukakannya, perpindahan itu disebabkan oleh semakin tersobudinasinya fungsi murni mesjid sebagai tempat shalat oleh kegiatan-kegiatan halaqah yang terus memadat, dan mulai diterapkannya tradisi bahtsul masail dengan metodel jadal (debat) yang sedikit banyak menimbulkan kegaduhan. Di samping itu, mengutip pendapatnya Von Kremers dalam Kudha Bukhsh: Islamic Civilization, didorong pula oleh adanya alasan profesionalisasi bagi guru-guru yang menghabiskan waktunya untuk kegiatan mengajar. ${ }^{3}$

Dari uraian tersebut di atas, dapat kita tangkap sebuah pemahaman bahwa munculnya madrasah merupakan upaya formalisasi pendidikan Islam, sesuai dengan kebutuhan umat saat itu yang menghajatkan adanya tempat khusus bagi kegiatan belajar mengajar.

Sepanjang penelitian tentang madrasah pada era klasik ${ }^{4}$ ini, ternyata kemunculannya tidak semata dilatari oleh hal-hal yang bersifat academic oriented seperti yang dikemukakan oleh Ahmad Syalabi di atas, tetapi juga erat kaitannya dengan supremasi yang diberikan oleh satu otoritas paham keagamaan tertentu bagi cara dan seperti apa seharusnya pengembangan ilmu itu bergulir. Bagaimana proses ini terjadi, dan lantas apa saja yang dikaji pada madrasah di era klasik tersebut sebagai bagian integral dari keseluruhan gerakan intelektual yang turut memformat arah perkembangan intelektual Islam? dua persoalan ini yang menjadi stressing point uraian tulisan.

\section{Akar historis Cikal Bakal Lahirnya Madrasah}

Kajian di sekitar munculnya madrasah di dunia Islam,banyak sejarahwan pendidikan Islam yang berbeda pendapat. Ahmad Syalabi menyatakan bahwa madrasah yang mula-mula muncul di dunia Islam adalah Madrasah Nizhamiyah yang didirikan oleh Nizham al-Mulk, Perdana Menteri Dinasti Saljuk, pada tahun 1065-7. Philip K. Hitti juga mengemukakan pendapat seperti ini. ${ }^{5}$ Berbeda dengan kedua sejarahwan

${ }^{2}$ Lihat George Mahdisi, The Rise of Colleges: Institutions of Learning in Islam and W'est, Edinburgh: Edinburgh University Press, 1981, h. 27-28. Lihat pula Ahmad Syalabi, Op.cit., h. 106-108.

${ }^{3}$ Ahmad Syalabi, Op,cit., h. 108.

${ }^{4}$ Masa klasik yang dimaksud adalah masa klasik Islam, yaitu kurun waktu yang terbentang antara tahun 650 M - 1250 M. Lihat lebih lanjut Harun Nasution, Pembaharuan dalam Islam: Sejarab Pemikiran dan Gerakan, Jakarta: Bulan Bintang, cet. ke-8, 1991, h. 13.

${ }^{5}$ Lihat Ahmad Syalabi, Ibid., b. 110; dan Philip K. Hitti, Histori of the Arab, London: MacMillan Press Ltd., 1974, h.410). 
tersebut, al-Maqrizi, sebagaimana dikutip oleh Athiyah al-Abrasyi, mengemukakan bahwa madrasah yang pertama kali didirikan adalah Madrasah al-Baihaqiyah pada akhir abad ke-4 H (abad ke-1 M). ${ }^{6}$ Penelitian lebih akhir dilakukan oleh Richard Bulliet. Ia melaporkan bahwa ada 39 madrasah di wilayah Persia yang berkembang dua abad sebelum berdirinya Madrasah Nizhamiyah. Pendapat ini didukung oleh sejarahwan pendidikan Islam, Nadi Ma'ruf, yang menyatakan bahwa di Khurasan telah berkembang madrasah 165 tahun sebelum kemunculan Madrasah Nizhamiyah. Selanjutnya, 'Abd al-'Al menyatakan, pada masa Sultan Mahmud al-Ghaznawi (berkuasa 388-421 H/998-1030) juga terdapat Madrasah Sa'idiyyah.'

Suatu pekerjaan yang agak sulit untuk memastikan pendapat mana yang paling tepat dari beberapa pendapat diatas. Namun demikian, merujuk pada telaah Hanun Asrohah dalam tesisnya berjudul "Peranan Pendidikan Islam terhadap Perkembangan Pemikiran Islam: kajian Historis tentang Pendidikan Islam di masa Dinasti Abbasiyah", secara eksplisit menyatakan bahwa Madrasah Nizhamiyah merupakan tonggak pertama dari bentuk madrasah.Kesimpulan ini didasarkan pada anggapannya bahwa terdapat kemungkinan penentuan Ahmad Syalabi dan Philip H. Hitti tersebut berangkat dari popularitas Madrasah Nizhamiyah yang terkenal dalam sejarah Islam dan sering disebut-sebut dalam buku sejarah Islam, tidak terkecuali dalam Ensiklopedi Islam. ${ }^{8}$ dari beberapa madrasah yang disebut, Madrasah Nizhamiyah lebih mendapat perhatian.

Madrasah Nizhamiyah yang terkenal itu memiliki komitmen berpegang teguh pada doktrin Asy'ariyah dalam kalam ("theologi") dan ajaran Syafi'i dalam fikih.? Memang pada awal kelahirannya, secara politis pendirian Madrasah Nizhamiyah oleh Nizham al-Mulk (W. 485 H/1092)yang juga mendirikan beberapa madrasah sejenis di Irak, Khurasan, Naisabur, Balkan dan Herat (Iran) ${ }^{10}$ itu dilatarbelakangi oleh upaya Bani Saljuk untuk menghidupkan kembali paham Sunni di Baghdad yang sebelumnya didominasi oleh Dinasti Buwaihi yang berpaham, Syi'ah. Di awal abad ke-11 M ini merupakan titik awal kemenangan Golongan Sunni atas Syi'ah yang ditandai dengan kemenangan Bani Saljuk atas Dinasti Buwaihi di Irak.

Perlu dicatat bahwa upaya penyebaran paham Sunni ini selain untuk mengikis faham keagamaan ala Syi'ah maupun praktek-praktek keagamaannya, juga merupakan refleksi atas ortodoksi faham mu'tazilah yang dianggap terlalu mendewakan akal, ortodoksi paham sufi ekstrim yang diklaim Zindig, semisal faham wihdaul wujud atau hulul.

Dari latar belakang historis tersebut di atas, dapatlah dikatakan bahwa Madrasah Mizhamiyah merupakan prototipe Madrasah Sunni yang mempunyai kepentingan ${ }^{6}$ Athiyah al-Abrasyi, Dasar-dasar Pokok Pendidikan Islam, terd. Bustami A. Gani dan Djohar Basri L.I.S., Jakarta: Bulan Bintang, cet. ke-7, 1993

${ }^{7}$ AzyumardiAzra, Pendidikan Tinggi Islam; Sebuab Pengantar dalam Charles Michael Stanton, Pendidikan

Tinggi dalam Islam, terj. H. Afandi dan Hasan Asari, Cet. 1, Jakarta : Logos, 1994, h.vi.

${ }^{8}$ Lihat HanunAsrohah, Se3arah Pendidikan Islam, Jakarta: Logos, 1999, h. 101. Lihat pula H.A.R. Gibb and J.H. Kramers (Ed.), Shorter Encyclopaedia of Islam, Leiden: E.J. Brill, 1961, h. 302304.

${ }^{9}$ AzyumardiAzra, Jaringan Ulama ; Timur Tengah dan Kepulauan Nusantara Abad XVII dan XVIII, Bandung: Mizan, 1994, h. 62.

${ }^{10}$ H. A. R. Gibb and J. H . Kremers (Ed: ), Op. cit , h. 303 
mendasar upaya penyebaran ajaran-ajaran sunni. Tidak aneh kalau kemudian Bulliet menyebut madrasah sebagai"theSunni Revival" (kebangkitan Golongan Sunni), ${ }^{11}$ lantaran pada masa itu, madrasah didirikan untuk menghasilkan birokrat-birokrat "ortodoks" bagi pemerintahan Bani Saljuk untuk melawan propaganda Syi'ah, mengikis ajaran mu'tazilah dan tasawuf ekstrim.

Bersamaan dengan terdiskreditkannya Golongan Syi'ah, pada masa ini golongan rasional di bidang kalam, yaitu Mu'tazilah --seperti disinggung di atas-- juga telah mengalami kemunduran popularitasnya. Hal ini berawal dari sikap antipati masyarakat ketika itu terhadap doktrin-doktrin rasional mu'tazilah yang lebih diakibatkan oleh implikasi peristiwa Mihnah(inquisition; dalam sejarah masa kegelapan Barat), pemeriksaan paham pribadi) ${ }^{12}$ yang berdarah, di mana seseorang akan diancam dibunuh atau disiksa manakala mengingkari paham bahwa Al-Qur'an itu hadits (baharu). Disamping itu dari pihak penguasa sendiri, yakni pada masa kekuasaan al-Mutawakkil sekitar tahun $848 \mathrm{M}$, berusaha menghapus mu'tazilah dan beralih mendukung golongan Sunni, kelompok mayoritas umat Islam ketika itu.

Umat Islam terus bersikap antipati terhadap ilmu-ilmu rasional. Dan lambat laun rasionalisme pun tidak mendapat tempat lagi dalam kegiatan pendidikan Islam. Untuk selanjutnya aktivitas pendidikan Islam memprioritaskan pengajaran ilmu-ilmu keagamaan, khususnya di bidang fikih.

Demikianlah dengan kondisi sosial-politik saat itu, Madrasah Nizhamiyah di Baghdad yang arsiteknya adalah Abu Sa'id al-Shafi ${ }^{13}$ itu pada perkembangan selanjutnya diikuti oleh berdirinya madrasah-madrasah lain, baik yang dibangun oleh Nizam al-Mulk sendiri maupun oleh penguasa-penguasa yang lainnya. Di Damascus misalnya, penguasa Nuruddin al-Zanky mengikuti sejak Nizham al-Mulk mendirikan madrasah di sana, yang akhirnya juga menyebar di kota-kota Syiria sampai ke desadesa. Madrasah terbesar yang didirikannya adalah an-Nuriyah al-Kubra.Tindakan Nuruddin ini memotivasi penduduk Damascus untuk turut mendirikan madrasah. Gubernur-gubernur dan keluarga Nuruddin juga mendirikan madrasah. Aktivitas ini berlangsung sampai abad ke-15. Pada abad ke-13 M terdapat 60 madrasah untuk Mazhab Syafi'i, 52 untuk Mazhab Hanafi,4 madrasah Mazhab Maliki, 10 madrasah Mazhab Hambali.

Shalah al-Din al-Ayyubi juga memiliki reputasi besar sebagai pendiri madrasah. Pada masa ini menurut al-Magrizi (wafat 845 H/1442 M), seperti dikutip Hillenbrand, telah berdiri 73 madrasah: 14 untuk Mazhab Syafi'i, 4 untuk Mazhab Maliki, 10 untuk Mazhab Hanafi, 3 untuk Mazhab Syafi'i dan Maliki, 6 untuk Mazhab Syafi'i dan Hanafi, 34 untuk empat Mazhab, 2 buah untuk Dar Hadits dan lain-lain. ${ }^{14}$ Pendirían madrasahmadrasah ini juga dimotori oleh komunitas dermawan yang punya kemampuan sosial dan ekonomi.

\footnotetext{
${ }^{11}$ Hanun Asrohah, Op. cit., h. 109.

${ }^{12}$ Mihnah atau pengujian akidah bertitik tolak dari ajaran bahwa syirk adalah dosa besar yang tidak bisa diampuni. Mengakui Al-Qur'an itu kekal adalah syirk karena yang kekal hanya Allah. AlQur'an adalah ciptaan Allah, oleh karena itu bersifat hadits (baharu). Lihat lebih lanjut Harun Nasution, op. cit., Jakarta: UI Press, 1986, h, 54 dan 61-89.

${ }^{13}$ Ahmad Syalabi, Op. cit., h. 112.

${ }^{14}$ Lihat Ahmad Syalabi, Ibid., h.112-129, lihat pula HanunAerohah, Op. cit., h. 109-111.
} 
Perkembangan penting yang patut dicatat di sini adalah terjadinya pelenturan di bidang fikih (tidak dibidang kalam) dalam penyelenggaraan madrasah yang sudah menjadi lembaga pendidikan tipikal muslim saat itu. Hal ini terlihat dari sejumlah madrasah non-Mazhab Syafi'i sebagaimana tersebut di atas. Dari sini dapat kiranya kita angkat satu tesis bahwa komunitas fiqih adalah komunitas yang toleran dalam peta perkembangan masyarakat Islam.

\section{Kurikulum Madrasah: Arah Perkembangan Intelektual Islam}

Sebelum masa kebangkitan madrasah-madrasah, ilmu-ilmu yang diajarkan di beberapa sarana seperti Kuttab, Majlis, Masjid dengan khalaqahnya dan Khan itu berpusat pada pengajaran Al-Qur'an sebagai pelajaran utama. Menurut Philip K. -Hitti, Al-Qur'an menjadi buku bacaan untuk pelajaran membaca, dan kemudian dipilih beberapa ayat untuk pelajaran menulis. ${ }^{15}$ Pelajaran baca tulis memang pelajaran dasar pada Kuttab. Demikian pula pada sarana-sarana yang lain Al-Qur'an menjadi primadona pengajaran, yang kemudian diperluas dengan mengajarkan hadits, tafsir, ilmu bahasa seperti nahwu dan adab. Adapun pengajaran fikih mulai mendapatkan tempatnya yang pasti di mesjid melalui jami'-jami' yang dipimpin seorang syikh yang mengajarkan fikih salah satu mazhab. ${ }^{16}$

Ketika madrasah sudah muncul, Al-Qur'an masih menjadi poros. Disiplindisiplin yang perlu untuk memahami dan menjelaskan Al-Qur'an tumbuh sebagai bagian inti dari pengajaran yakni hadits, lalu tafsir. Hadits diajarkan dengan metode menghafal secara literal yang ratusan jumlahnya. Adapun Tafsir sangat bergantung dari kemampuan seorang syikh dalam mengajarkan metode-metode tafsir dan penjelasan bahasa Al-Qur'an. Ilmu retorika juga mendapat perhatian di samping juga pengetahuan sejarah dan geografi serta kesadaran umum tentang sistem pemerintahan dan sistem sosial. ${ }^{17}$ Bagaimanapun, ilmu-ilmu yang tersebut terakhir ini tidaklah begitu menarik (tidak mendapat respon yang kuat) dibandingkan kajian Al-Qur'an dan Hadits.

Pada perkembangan selanjutnya fikih mendapat tempat dalam kurikulum madrasah sebagai satu bidang kajian khusus dalam mazhab tertentu, di mana ilmu-ilmu lain berfungsi sebagai prasyarat. George Mahdisi mencatat bidang studi usul-fikih; prinsip-prinsip, sumber-sumber dan metodologi hukum Islam merupakan salah satu bidang yang pasti dalam kurikulum madrasah. ${ }^{18}$

Menurut Charles Michael Stanton, teologi dan filsafat tidak tumbuh sebagai bagian dari kurikulum pendidikan tinggi formal (madrasah) sebab figur muslim yang saleh adalah yang menerima sepenuhnya ajaran-ajaran Islam seperti dinyatakan dalam Al-Qur'an dan percaya bahwa semua pengetahuan yang penting terdapat dalam AlQur'an. Selanjutnya Stanton menyebutkan bahwa studi di bidang teologi dan filsafat ini dilakukan secara pribadi dalam pusat-pusat pendidikan non-formal, sangat sedikit tulisan para ahli muslim di bidang ini masuk pada kurikulum madrasah. ${ }^{19}$

\footnotetext{
${ }^{15}$ Philip K. Hitti, Op.cit., h. 408.

${ }^{16}$ Lihat HanunAerohah, Op.cit., h. 57.

${ }^{17}$ Charles Michael Stanton, Op. cit., h, 55.

${ }^{18}$ George Mahdisi, Op.cit., h. 80

${ }^{19}$ Charles Michael Stanton, Op.cit., h. 54.
} 
Ilmu-ilmu seperti matematika, logika, astronomi, zoologi, botani, antropologi dan psikologi memang ada tercatat dalam cakupan kurikulum pada abad ke-10 M. Misalnya catatan yang bersumber pada Ikhwan al-Shafa', suatu persaudaraan sufi yang mengabdikan diri bagi peningkatan pendidikan di dunia Islam, mencatat disiplindisiplin ilmu tersebut. Namun, menurut Stanton ilmu-ilmu yang dikatagorikan oleh Ikhwan al-Shafa' ke dalam kelompok ilmu-ilmu filosofia itu bukan merupakan bagian dari pendidikan yang ditawarkan di madrasah, lebih-lebih di mesjid. ${ }^{20}$

Ketiadaan nuansa profan dalam konstruksi kurikulum formal madrasah di masa klasik ini dipertegas oleh sejarahwan masa kini, yakni Azyumardi Azra. Menurutnya kemajuan peradaban Islam masa klasik sebelum khalifah al-Ma'mun yang ditandai dengan pesatnya sains dan (penterjemahan buku-buku filsafat Yunani) hampir bisa dipastikan bukan muncul dari madrasah. Kemajuan sains di kalangan masyarakat muslim lebih merupakan hasil dari individu-individu ilmuwan muslim yang didorong oleh semangat "Scientific inquiry"(penyelidikan ilmiah) guna membuktikan kebenaran ajaran-ajaran Al-Qur'an, terutama yang bersifat kauniyah.

Menurutnya lagi memang terdapat beberapa madrasah al-Thibb(madrasah kedokteran) seperti yang dikemukakan Faruqi dalam Cultural Atlas of Islam, tetapi madrasah kedokteran ini tidak dapat mengembangkan ilmu kedokteran dengan bebas, karena sering digugat kalangan fuqaha. Misalnya, mereka tidak memperkenankan penggunaan organ-organ mayat sekalipun dibedah untuk diselidiki. Sama halnya dengan rumah sakit-rumah sakit riset, seperti terdapat di Kairo dan Baghdad, terhalang oleh legalitas dan otoritas fikih, sehingga pada akhirnya terpaksa berkonsentrasi pada ilmu kedokteran teoritis dan keperawatan. ${ }^{21}$

Ilmu-ilmu non-agama seperti filsafat, hukum dan kalam berkembang pada halaqah-halaqah yang diadakan oleh komunitas bebas dan non formal. Tetapi sekali lagi, karena madrasah dengan kajian keagamaan tersebut itulah yang menjadi perhatian penguasa dan kalangan dermawan maka kajian-kajian non keagamaan dalam komunitas masyarakat bebas itu tetap berada pada posisi marginal.

Walhasil, kurikulum madrasah didominasi oleh ilmu-ilmu agama (al "Ulum al diniyyah) dengan penekanan khusus pada bidang fikih, tafsir dan hadits. Meskipun ilmu-ilmu seperti ini memberi ruang gerak pemberdayaan akal untuk melakukan ijtihad, namun jelaslah bukan dimaksudkan sebagai sebuah legitimasi penggunaan akal seluasluasnya.Ia lebih berarti pemberian penafsiran baru yang tetap berada pada wilayah doktrin yang mapan dalam paham Sunni yang menempatkan akal di bawah wahyu.

Pada masa ini, peran ijtihad pun sebenarnya Nampak menyempit dan akhirnya lenyap. Ini terjadi menurut Ahmad Jainuri ketika fikih muncul sebagai sistem hukum Islam dan adanya anggapan bahwa kebutuhan pengembangan prinsip baru dianggap sudah tidak ada. Gejala inilah yang kemudian dikenal dalam sejarah jurisprudensi Islam sebagai tertutupnya pintu ijtihad yang diyakini kaum muslimin sejak abad ke-4 H. ${ }^{22}$

${ }^{20}$ Ibid., h. 57.

${ }^{21}$ AzyumardiAzra, Pendidikan Tinggi Islam dan Kemajuan Sains (sebuah pengantar) dalam Charles Miohae L Stanton, Ibid., h. viii.

${ }^{22}$ Lihat Achmad Jainuri, Landasan Teologia Gerakan Pembaharuan Islam, dalam Jurnal Ilmu dan Kebudayaan “Ulumul Qur’an Nomor 3 Vol. VI th. 1995. 
Mengapa sebenarnya ilmu-ilmu agama ini mengedepan dalam konstruksi kurikulum madrasah, sementara ilmu-ilmu non-agama (profan) khususnya ilmu-ilmu alam dan eksakta--merupakan akar pengembangan sains dan teknologi-sejak awal perkembangan madrasah berada pada posisi marginal?

Ahmad Syalabi memberikan jawabannya bahwa pembahasan tentang pendidikan Islam tentu menyiratkan pengetahuan agama sebagai kontennya, di samping adanya kepentingan penguasa untuk berkhidmat pada ajaran sunni yang dianggap paling benar. $^{23}$

Dalam penglihatannya yang lebih spesifik pada legalitas dan otoritas fikih, Azyumardi Azra mengemukakan pendapatnya tentang mengapa sampai fikih dan ilmuilmu agama mengedepan, yakni pertama, berkaitan dengan adanya pandangan tentang ketinggian ilmu syari'ah dan ilmu-ilmu keagamaan lainnya. Kedua, secara institusional lembaga-lembaga pendidikan Islam (madrasah) memang dikuasai oleh mereka yang ahli dalam bidang-bidang agama. Dan Ketiga, berkenan dengan kenyataan bahwa hampir seluruh madrasah didirikan dan dipertahankan dengan dana wakaf baik dermawan kaya atau penguasa politik muslim. Mereka lebih memandang bahwa motivasi kesalehan lebih terletak pada aktivitas yang bergerak dalam lapangan ilmu-ilmu agama, lebih mendatangkan pahala ketimbang di bidang ilmu-ilmu yang beraura profan. ${ }^{24}$

Analisa sosial yang lain dapat pula dikemukakan bahwa mobilitas komunitas dermawan untuk menghidupkan madrasah ini didorong pula oleh keinginan mereka untuk hidup damai, jauh dari kekacauan-kekacauan politik. Trend hidup damai ketika itu adalah dengan memperbanyak ibadah dan menghidupkan ilmu-ilmu agama, sesuai dengan ajaran para ulama ketika itu yang sangat banyak dipengaruhi ajaran-ajaran Al-Ghazali.

Demikian perwajahan konstruksi kurikulum madrasah yang tumbuh pada era klasik selama kurang lebih satu setengah abad lamanya sejak berdirinya Madrasah Mizhamiyah yang dianggap peletak utama madrasah sebagai pendidikan tipikal Islam saat itu. Dalam jangka waktu yang tidak sebentar itu, tentu madrasah merupakan agen utama dalam memformat arah perkembangan intelektual Islam yang sangat bercorak ilmu agama konvensional itu. Kenyataan seperti ini tentu menjadi sasaran kritik utama pada masa-masa setelahnya, terutama pada masa pembaharuan yang tidak pada porsinya dibicarakan pada makalah ini. Walau begitu, satu apresiasi yang bijak apabila kita tetap menganggap bahwa perwajahan madrasah di masa klasik ini hadir sesuai dengan kondisi zaman saat itu. Sebagai mata rantai sejarah tentunya memiliki kontribusi bagi perkembangan pendidikan Islam selanjutnya.

\section{Simpulan}

Tumbuh dan berkembangnya madrasah di bawah patronasi Sunni pada masa klasik jika dipandang semata-mata dari sudut keagamaan, maka agaknya mengandung implikasi positif, yakni terjadinya pemantapan fikih sebagai salah satu inti Islam sehingga lebih menjamin transmisi ilmu ini bagi generasi-generasi berikutnya. Namun

${ }^{23}$ Ahmad Syalabi, Op. bit., h. 109.

${ }^{24}$ AzyumardiAzra, Pendidikan Tinggi Islam dan Kemajuan Saine (sebuah pengantar) dalam Char1ee Michae1 Stanton, Op. cit., h. ix. 
demikian, jika dilihat dalam perspektif yang lebih luas, supremasi ilmu-ilmu agama memiliki dampak substansial, tidak saja pada perkembangan ilmu dalam Islam tapi juga peradaban Islam secara keseluruhan. Dalam konteks lini terjadi dualism hirarkis ilmu, ilmu agama lebih utama dari ilmu profan. Fenomena ini kemudian dipandang sebagai problem ilmu dalam peradaban Islam yang tidak mudah untuk dicairkan hingga hari ini.

Dalam bingkai plus-minusnya perkembangan madrasah di era klasik ini, kiranya proses historis yang menggiring perkembangan madrasah ketika itu dijadikan sebagai cermin yang seyogyanya menimbulkan refleksi. Dan pada gilirannya menimbulkan upaya-upaya kreatif dalam rangka upaya pembaharuan lembaga-lembaga pendidikan Islam masa kini dan akan datang.

\section{Daftar Pustaka}

Abrasyi, M. Athiyah, al-, Dasar-dasar Pokok Pendidikan Islam, terj . H. Bustami A. Gani dan Djohar Bahry L. I .S. , Jakarta: Bulan Bintang, Cet, ke-7, 1993.

Aerohah, Eanun, Sejarah Pendidikan Islam, Jakarta: Lagoe,1999.

Azra, Azyumardi, Jaringan Ulama; Timur Tengah dan Kepulauan Nusantara Abad XVII dan XVIII, Bandung: Mizan, 1994.

Gibb, H. A. B. and Kremers, J .M., Shorter Encyclopaedia of Islam, Leiden: E.J. Brill, 1961.

Hitti, Philip K., History of the Arab, London: Macmillan Press Ltd., 1974.

Jainuri, Achmad, Landasan Teologie Gerakan Pembaharuan Islam, dalam Jurnal Ilmu dan Kebudayaan "Ulumul Qur'an", Nomor 3 Vol. VI, Th. 1995.

Mahdisi, George, The Rise of Colleges: Institutions of Learning in Islam and the West, Edinburgh: Edinburgh University Press, 1981.

Nasution, Barun, Pembaharuan dalam Islam: Sejarah Pemikiran dan Gerakan, Cet. ke-8, Jakarta: Bulan Bintang, 1991.

Stanton, Charrles Michae L, Pendidikan Tinggi dalam Islam, terj. H.Affandi dan Hasan Asari, Jakarta: Logos,1994.

Byalabi, Ahmad, Sejarah Pendidikan Islam, terj Muchtar Jahja dan M. Sanusi Latief, Cet. ke-1, Jakarta:Bulan Bintang, 1973.

Tibawi, A. L., Islamic Education : It a Traditions and Modernization into the Arab National Systems, London: Luzac and Company Ltd. , 1972.

Zuhairini, Sejarah Pendidikan Islam, Jakarta: Bumi Aksara,1992. 